\title{
Pelatihan public speaking bagi siswa SMA Negeri 5 Barru
}

\author{
$\mathrm{Usman}^{1}$, Hajrah $^{2}$ \\ ${ }^{1,2}$ Fakultas Bahasa dan Sastra, Universitas Negeri Makassar
}

\begin{abstract}
The Community Partnership Program (PKM) partner is OSIS SMA 5 Barru. The problem is: (1) low motivation in speaking activities, especially in public. The lack of confidence is always experienced by students, so there is no courage to speak in public and (2) limited knowledge, techniques, experience, and public speaking skills. The method used is three stages, namely (1) providing material, (2) practice or simulation, and (3) mentoring. The results achieved are (1) partners have motivation, enthusiasm, and self-confidence can speak in public and (2) partners have knowledge, techniques, experience, and skills when speaking in public, including in supporting activities in carrying out activities in school and community.
\end{abstract}

Keywords: training, public speaking, speaking

\section{PENDAHULUAN}

Setiap guru bahasa dan sastra Indonesia pada berbagai jenjang pendidikan mengharapkan siswanya terampil berbicara. Keterampilan ini sebagai upaya untuk meningkatkan kemampuan berkomunikasi secara lisan sehingga dapat berkomunikasi dalam berbagai konteks secara efisien dan efektif. Melalui keterampilan berbicara, siswa akan mampu mengungkapkan ide, pikiran, dan informasi dengan cara yang benar di depan umum dan tidak menimbulkan kesalahpahaman (Lucas, 2002). Fenomena di sekolah saat ini, khususnya di tingkat SMA, masih banyak siswa mengalami kesulitan untuk berkomunikasi/berbicara secara lisan dalam situasi formal, termasuk di kelas. Ketika guru menyampaikan pertanyaan, tidak seorang pun siswa yang memiliki keberanian untuk menjawab. Demikian juga, ketika guru memberikan kesempatan kepada siswa untuk bertanya. Hampir tidak pernah ada seorang siswa pun yang mau bertanya kepada guru, padahal masih banyak materi ajar yang belum mereka dikuasai.

Berbicara sangat penting bagi eksistensi sosial dan budaya siswa. Siswa yang terampil berbicara akan mampu merealisasikan budaya santun dalam berkomunikasi dengan lawan bicaranya. Dengan demikian, keterampilan berbicara harus dikuasai oleh setiap siswa yang diawali dari pembelajaran di sekolah sebagai pendidikan formal. Pembelajaran berbicara semakin menunjukkan kekurangannya dan tidak mampu mencapai standar yang ditetapkan. Berdasarkan hasil pengamatan dan hasil wawancara, dapat disimpulkan bahwa hanya sekitar $20 \%$ siswa yang sudah memiliki keberanian untuk berbicara di depan kelas atau di depan umum. Selebihnya, tidak mampu mengomunikasikan pesan dalam berbagai konteks. Hasil ini tentunya sangat melenceng dari target pencapaian pembelajaran bahasa Indonesia yang mengharuskan mencapai standar ketuntasan minimal (SKM), yaitu $75 \%$ siswa harus mampu dan terampil berbicara.

Berdasarkan hal tersebut, wajar jika banyak siswa yang tidak mampu berbicara secara efektif dalam berbagai konteks dan situasi. Hal ini karena berbicara bukanlah suatu pengetahuan yang mudah dicapai. Hal ini memerlukan berbagai keterampilan dan pengetahuan sebagai daya pendukung untuk menyampaikan pesan. Kemampuan berbicara setiap orang sangat bervariasi. Ada yang mampu berbicara dengan lancar, tetapi penyajian topik pembicaraannya kurang menarik sehingga menimbulkan kebosanan bagi penyimaknya. Ada pula pembicara yang hanya menyajikan topik biasa-biasa saja, tetapi justru menarik karena disajikan dengan gaya dan cara yang tepat.

Mencermati kondisi tersebut, guru harus bertindak cepat dengan mengupayakan metode pembelajaran yang sesuai dengan minat dan karakter siswa. Hal ini dimaksudkan agar tujuan 
pembelajaran bahasa Indonesia sesuai dengan kurikulum, yaitu siswa diharapkan mampu berbicara secara efektif dan efisien untuk mengungkapkan gagasan, pendapat, kritikan, perasaan, dalam berbagai bentuk kepada mitra bicara sesuai dengan tujuan dan konteks pembicaraan (Adri, 2011). Siswa kelas SMA Negeri 5 Barru diharapkan memiliki keterampilan berbicara. Hal ini bertujuan untuk keperluan interaksi sosial dengan siswa dan lingkungan sekitarnya. Siswa akan mengenal dan memahami segala konsep yang dihadapi jika ia terampil berbicara. Bagi siswa, penguasaan teori berbicara bukanlah menjadi tujuan utama dalam pembelajaran berbicara, melainkan yang terpenting dalam pembelajaran berbicara adalah siswa mampu berbicara sesuai dengan konteks. Pembelajaran berbicara harus berorientasi pada aspek penggunaan bahasa, bukan pada aturan pemakaiannya.

Pembelajaran berbicara di kelas semestinya diarahkan untuk membentuk kepribadian anak yang terampil berkomunikasi secara lisan, seperti mampu berdebat, mengemukakan pendapat, bercerita, berdialog, dan bahkan berpidato tanpa teks. Tingkat perkembangan intelektual siswa SMA (yang diperkirakan rata-rata umur siswa 15 tahun ke atas) sudah berada pada tingkat operasional formal yang sangat membantu dalam proses pembelajaran berbicara. Di tahap ini, siswa tidak memerlukan bantuan benda-benda kongkret untuk berpikir karena siswa sudah mampu berpikir abstrak.

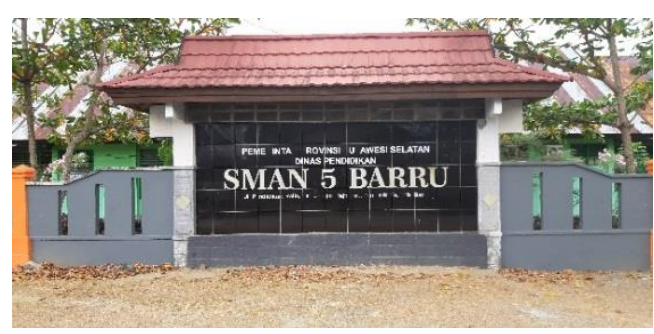

Gambar 1. SMA Negeri 1 Barru

Berdasarkan hal tersebut, merasa perlu mengadakan pelatihan berbicara (public speaking) bagi siswa SMA Negeri 5 Barru. Dipilihnya siswa (pengurus OSIS) SMA 5 Barru sebagai objek Program Kemitraan Masyarakat (PKM) ini disebabkan oleh beberapa faktor, di antaranya observasi awal oleh Tim PKM di sekolah ditemukan kecenderungan siswa belum terlalu mahir berbicara dan mengemukakan gagasan dan pikirannya, khususnya di depan umum. Pengurus OSIS SMA Negeri 5 Barru memiliki kemampuan public speaking rendah. Padahal, para pengurus OSIS diharapkan berperan penting dalam setiap kegiatan yang dilakukan di sekolah. Banyak kegiatan memerlukan keterampilan berbicara.

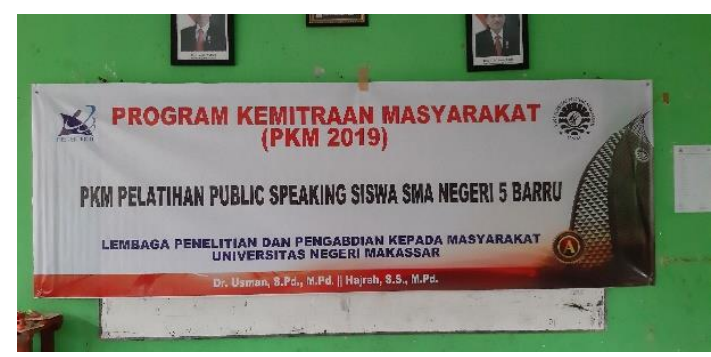

Gambar 2. Spanduk kegiatan PKM

Keterampilan berbicara di depan umum tidak semudah membalik telapak tangan. Kemampuan ini dapat dimiliki seseorang dengan jalan berlatih dan terus mempraktikkan dalam setiap kegiatan (Nugrahani et al., 2012). Berdasarkan hasil observasi yang telah dilakukan, permasalahan mitra adalah kompetensi public speaking atau berbicara siswa (pengurus OSIS), belum memadai. Walaupun bisa berbicara, namun masih ada beberap hal yang mereka belum kuasai, khususnya masalah teknis.

\section{METODE PELAKSANAAN}

Pelatihan didesain secara terstruktur dan berkesinambungan yang mencakup dua aspek utama; pemberian wawasan tentang public speaking dan praktik public speaking secara terbimbing dan berkelanjutan. Melalui pelatihan, siswa mitra yang menjadi sasaran diharapkan dapat memperoleh pengetahuan, teknik, pengalaman, dan keterampilan berbicara sehingga pada akhirnya mampu menerapkan berbagai metode, teknik, dan strategi berbicara tersebut dalam pembelajaran di kelas khususnya dan di depan umum pada umumnya. Pelatihan public speaking dibagi menjadi tiga tahap, yakni (1) pemberian materi public speaking 
melalui pelatihan, (2) kegiatan praktik atau simulasi public speaking, dan (3) pendampingan public speaking.

\section{HASIL DAN PEMBAHASAN}

Kompetensi public speaking atau berbicara di depan publik tidak perlu ditawar-tawar lagi. Kompetensi ini bisa menjadi salah pilihan atau alternatif bagi siapa saja yang ingin menjadikan public speaking sebagai profesi. Tidak bisa dihitung lagi berapa banyak orang yang telah menggeluti dunia public speaking terbilang sukses. Kesuksesan yang mereka raih berbanding lurus dengan kompetensi yang mereka miliki. Semua perkataan, penampilan, dan gerak-geriknya bisa menjadi inspirasi dan manfaat bagi siapa saja yang mendengarkannya.

Kegiatan PKM ini dilaksanakan selama tiga hari, sejak 20-22 September 2019. Tanggal 20 September 2019 menuju lokasi. Kemudian observasi lapangan dan persiapaan kegiatan. Tanggal, 21-22 September 2019, penyajian materi. Proses kegiatan berupa pemaparan materi oleh Dr. Usman, M. Pd., Hajrah, S.S., M.Pd., dan Dedi Gunawan Saputra, S.Pd., tanya jawab dan simulasi public speaking.

Materi yang disampaikan oleh pemateri, antara lain: survey tentang perasaan orang ketika berbicara di depan umum, pentingnya belajar public speaking, apa itu public speaking, metode public speaking (The Power of Visualisasi, Proses Latihan, Penggunaan Alat Bantu, Jurus Pembuka yang Memikat, Perhatikan VIJAT, Teknik Gerak Tubuh, Gerak Tangan, dan Mengapa Perlu Kontak Mata?), membina hubungan dengan audiens, penutup yang berkesan, komunikasi efektif, dan kekeliruan yang dilakukan pembicara.

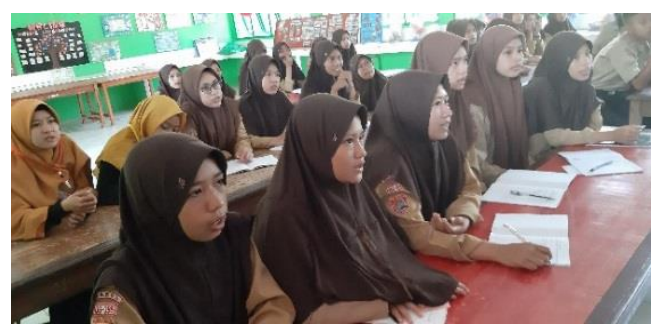

Gambar 3. Peserta antusias mendengar materi
Setelah penyajian materi, dilanjutkan sesi tanya jawab. Beberapa peserta sangat antusias bertanya. Beberapa pertanyaan yang diajukan seperti kiatkiat menjadi pembicara yang handal, cara mengatasi demam panggung, cara memulai berbicara di depan orang, apa yang harus dipersiapkan sebelum tampil berbicara di depan umum, dan sebagainya. Sesi selanjutnya latihan atau simulasi public speaking. Peserta dibagi ke dalam beberapa kelompok. Setiap kelompok masing-masing diberikan topik atau tema yang berbeda. Lalu peserta berdiskusi merumuskan topik atau tema yang diberikan.

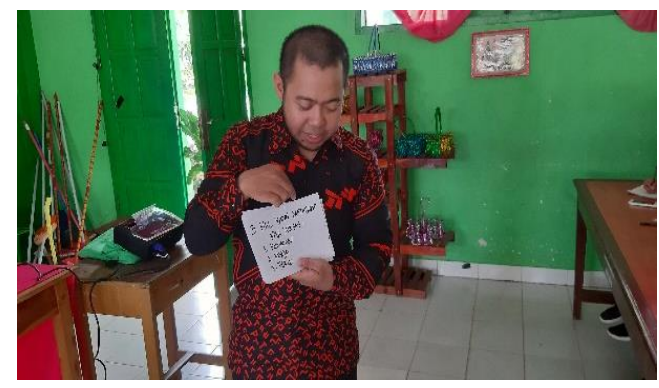

Gambar 4. Pemateri tema/topik pidato

Setelah merumuskan topik atau tema, selanjutnya mereka diminta untuk mencari bahan atau materi yang berkaitan dengan topik atau tema. Kemudian masing-masing kelompok ada perwakilan tampil berpidato. Hasilnya, siswa yang mengikuti pelatihan ini sangat antusias. Terlihat dari banyaknya siswa yang ingin melakukan simulasi untuk menjadi public speaker.

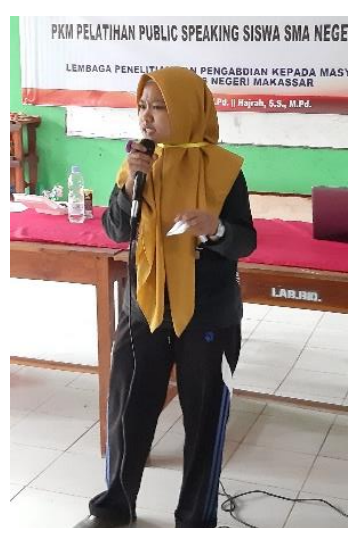

Gambar 5. Salah satu peserta mitra yang tampil berpidato 
Setelah dilakukan simulasi bagi peserta, selanjutkan salah seorang pemateri kembali melakukan simulasi berbicara di depan peserta sebagai pembawa acara/MC (master of ceremony). Pemateri menyampaikan meterinya, seperti teknik memandu acara (membuka dan menutup), penggunaan bahasa yang efektif dan vocal yang jelas (intonasi, speed, asentuasi atau penekanan kalimat, dan artikulasi atau pengucapan kata dan kalimat), penggunaan bahasa lisan dan gesture. Selain itu, materi kepribadian, penampilan, wawasan, dan komunikatif. Berbicara di depan umum bukan perkara mudah, termasuk siswa. Berbicara di depan kelas atau teman-temannya dalam siatuasi formal, berbiacara di depan forum atau audiens, membuat siswa tidak percaya diri atau demam panggung. Oleh karena itu, dibutuhkan seorang pembicara atau speaker harus punya keberanian, memiliki ilmu atau paham tentang apa yang akan disampaikan, harus memiliki suara yang keras dan jelas, dan juga harus didukung oleh alat bantu, seperti microphne, sound system, infocus, dan slide-slide yang akan memperlihatkan materi atau bahan tayang.

Beberapa siswa yang diminta komentarnya berkaitan dengan kegiatan pelatihan public speaking di SMA Negeri 5 Barru mengaku puas atas kegiatan ini. Mereka menganggap bahwa kegiatan ini penting karena selain belajar tentang apa itu public speaking, mereka juga belajar etika, teknik, strategi, dan cara meningkatkan rasa percaya diri ketika berbicara di depan orang. Apalagi ada praktik berbicara di depan peserta. Sebelum tampil, mereka dilatih mulai dari mencari topik dan referensi, kemudian mengembangkan, latihan, lalu tampil di depan teman-temannya. Salah satu peserta mengatakan, materi yang sangat penting dan menarik baginya adalah bagaimana menumbuhkan rasa percaya diri berbicara di depan teman-temannya sendiri.

\section{KESIMPULAN}

Pelatihan public spekaing sangat penting artinya bagi setiap orang, termasuk siswa dalam menunjang kemampuan berbicara di depan umum. Pelatihan ini memberikan pengetahuan, teknik, pengalaman, dan keterampilan kepada siswa dalam mendukung aktivitasnya dalam melakukan kegiatan di sekolah dan maupun masyarakat. Selain pengetahuan dan pengalaman, siswa juga mendapatkan manfaat dari kegiatan ini, yakni kemampuan public speaking yang dimiliki dapat menjadi alternatif profesi di masa yang akan datang. Hal ini bisa dilakukan, karena tim menyarakan kepada mitra akan adanya pendampingan untuk menggali potensi mitra, khususnya dalam bidang public speaking.

\section{DAFTAR PUSTAKA}

Adri. 2011. Peningkatan Keterampilan Berbicara dengan Menerapkan Teknik Debat Topik Siswa Kelas X SMA Negeri 3 Takalar. Jurnal Sawerigading. Volume 17, No. 2 Agustus 2011 halaman 189-202.

Lucas, Stephen E. 2002. The Art of Public Speaking. New York: Longman Inc.

Nugrahani, D. et al. 2012. Peningkatan Kemampuan Public Speaking Melalui Metode Pelatihan Anggota Forum Komunikasi Remaja Islam. Educatioan Jurnal Pengabdian Kepada Masyarakat. Vol. 3, No. 1. 